\title{
Distinct pattern of lymphoid neoplasms characterizations according to the WHO classification (2016) and prevalence of associated Epstein-Barr virus infection in Nigeria population
}

ljeoma C. Uzoma ${ }^{1,2}$ (D) Idowu A. Taiwo ${ }^{2,3}$, Massimo Granai ${ }^{4}$, Gioia Di Stefano ${ }^{5}$, Ester Sorrentino ${ }^{5}$, Sussana Mannucci ${ }^{5}$, Muheez A. Durosinmi ${ }^{6}$, Stefano Lazzi ${ }^{5}$, Lorenzo Leoncini ${ }^{5^{*}}$ and Oluyemi Akinloye ${ }^{3,7^{*}}$

\begin{abstract}
Background: The present study aimed to classify lymphoid neoplasms according to the latest World Health Organization (WHO) classification and outlining the distribution in Nigeria of different entities. Additionally, the study describes the prevalence of lymphoid neoplasms associated with Epstein-Barr virus (EBV) infection in the Nigerian population.
\end{abstract}

Methods: We collected 152 formalin-fixed paraffin-embedded (FFPE) tissues diagnosed as lymphoma from 2008 to 2018, coming from three different institutions located within three geopolitical zone in Nigeria. These institutions included the University College Hospital (UCH), Ibadan, Oyo State, the Enugu State University of Science and Technology Teaching Hospital (ESUTH), Enugu, Enugu State, and the Meena Histopathology and Cytology Laboratory (MHCL), Jos, Plateau State.

Results: From the total 152 cases retrieved, 50 were excluded due to insufficient tissue materials or inconclusive antigen reactivity. We confirmed $66(64.7 \%)$ cases as lymphomas out of the remaining 102 FFPE with a male to female ratio of 2:1 and a mean age of 44.4 years. Ten entities were identified, and of these, chronic lymphocytic leukemia (CLL) was the most prevalent category (34.8\%). For the diffuse large B-cell lymphomas not otherwise specified (DLBCL, NOS), the germinal centre B-cell type was the most common (71.4\%). Ten lymphoma cases (15.2\%) were positive for Epstein-Barr virus (EBV), most of which were Hodgkin lymphoma (HL). CLL was common in the Hausa ethnic group, $\mathrm{HL}$ in the Yoruba ethnic group, while the lgbo ethnic group had an equal distribution of $\mathrm{CLL}, \mathrm{HL}$, and DLBCL diagnosis.

\footnotetext{
* Correspondence: Iorenzo.leoncini@unisi.it; oakinloye@unilag.edu.ng

${ }^{5}$ Section of Pathology, Department of Medical Biotechnology, University of Siena, Siena, Italy

${ }^{3}$ Centre for Genomics of Non-communicable Diseases and Personalized Healthcare (CGNPH), University of Lagos, Lagos, Nigeria

Full list of author information is available at the end of the article
}

C C The Author(s). 2021 Open Access This article is licensed under a Creative Commons Attribution 4.0 International License, which permits use, sharing, adaptation, distribution and reproduction in any medium or format, as long as you give appropriate credit to the original author(s) and the source, provide a link to the Creative Commons licence, and indicate if changes were made. The images or other third party material in this article are included in the article's Creative Commons licence, unless indicated otherwise in a credit line to the material. If material is not included in the article's Creative Commons licence and your intended use is not permitted by statutory regulation or exceeds the permitted use, you will need to obtain permission directly from the copyright holder. To view a copy of this licence, visit http://creativecommons.org/licenses/by/4.0/ The Creative Commons Public Domain Dedication waiver (http://creativecommons.org/publicdomain/zero/1.0/) applies to the data made available in this article, unless otherwise stated in a credit line to the data. 
Conclusion: Although the distribution of lymphomas in Nigeria shares some similarities with those of other countries, we described distinct features of some subtypes of lymphomas. Also, the study underscores the need for a more precise diagnosis and classification of lymphoid neoplasms in Nigeria using the latest WHO classification.

Keywords: Lymphoid neoplasms, WHO classification, Epstein-Barr virus, Immunohistochemistry, In-situ hybridisation

\section{Introduction}

Lymphomas are a heterogeneous group of neoplasms based on genetically complex mechanisms that can be generally categorized as Hodgkin lymphomas (HL) or non-Hodgkin lymphomas (NHL) [1]. Also, lymphomas show a broad spectrum of clinical and pathological presentations, and in sub-Saharan Africa, they continue to be one of the primary causes of morbidity and mortality [2, 3]. Precisely, Nigeria has recorded an increasing incidence of NHL. NHL is reported as the 5th most common cancer by the national cancer registries [4, 5], and their definition and characteristics are ever-increasing and more complex since molecular and genetic features are constantly being identified to allow a more accurate diagnosis and prognosis [6].

Lymphoid neoplasms show ethnic and geographical differences in their distribution and molecular characteristics [7]. Unlike developing countries, substantial efforts have been made in developed nations to match each lymphoma category with advanced diagnostic tools: diagnosis, therapy, and prognosis $[8,9]$.

The classifications of Tumors of Haematopoietic and Lymphoid Tissues are now based on the latest investigations to identify and describe the tumor characteristics and were previously captured in the Revised EuropeanAmerican Classification of Lymphoid Neoplasms (REAL) system of classification in 1994 that was subsequently integrated into the World Health Organization classification (WHO) [6, 10-12].

Some infectious agents have been implicated as drivers of lymphomagenesis, including the Epstein Barr virus (EBV), human herpesviruses 8 (HHV-8), human immunodeficiency virus (HIV), and Plasmodium falciparum $[13,14]$. EBV is the most common etiological viral agent associated with lymphomagenesis and is present in endemic and sporadic Burkitt lymphoma (BL), Hodgkin lymphoma (HL), and diffuse large B-cell lymphoma, not otherwise specified (DLBCL, NOS) [15]. The EBV Encoded RNA (EBER) is present at the latent stage of developing the virus in EBV infected individuals [16]. The detection of all of these pathogens enables appropriate therapeutic measures to reduce disease burden and improve the overall survival of lymphoma patients in Nigeria. There is a need even more to understand the distribution and spread of these malignancies in Nigeria using more thorough investigations. The lack or limited availability of these tools in low and middle-income countries makes accurate diagnosis and classification of lymphoid neoplasms difficult or practically impossible. Consequently, in these countries, patients' overall survival with lymphoid malignancies is meager $[17,18]$. Many Nigerian institutions still employ only histomorphological characterization, leading to misdiagnosis and resulting in improper treatment [19].

The present study aimed to reclassify lymphoma cases from three different medical institutions in Nigeria that were diagnosed by analyzing only the morphological features with Hematoxylin-Eosin (H\&E) staining and then evaluate the differences between the original and the revised diagnosis. Moreover, we aimed to determine in the study cohort the prevalence of EBV in different lymphoma subtypes and the frequency of DLBCL subtypes using the Hans algorithm [20].

\section{Material and methods Study cohort}

Formalin-fixed paraffin-embedded (FFPE) biopsies, including their demographic data, were collected from tertiary facilities of three different geopolitical areas in Nigeria: University College Hospital, Ibadan, Oyo State, Enugu State University of Science and Technology Teaching Hospital (ESUTH), and Meena Histopathology and Cytology Laboratory, Jos, Plateau State. Ethical committee approvals were obtained from the University of Nigeria Teaching Hospital, Enugu (UNTH-NHREC/05/ 01/2008B), Ministry of Health, Ibadan, Oyo State (AD13/479/1138), and Meena Histopathology and Cytology Laboratory, Jos, Plateau State (MEENALAB/AEC/ 177). A total of 152 FFPE morphologically diagnosed as lymphoid neoplasms in the already listed institutions between 2008 and 2018 were obtained. The revised classification was made according to the latest WHO classification of Tumors of Lymphoid Tissues. The statistical analysis was done with IBM, SPSS version 25.0 software package (IBM ${ }^{\circ}$ Software). The level of statistical significance was set at $p<0.05$. Inferential statistics were t-test in case of 2 groups and ANOVA in case of 3 or more groups with continuous normally distributed variables. Significant ANOVA results were followed by Tukey post hoc test for paired comparison. Association between variables was by Pearson product-moment correlation $(\mathrm{r})$ and Chi-square $\left(\mathrm{X}^{2}\right)$ test for independence. 
Table 1

\begin{tabular}{|c|c|c|c|c|c|c|c|c|c|c|c|}
\hline $\begin{array}{l}2016 \text { WHO LYMPHOMA } \\
\text { CLASSIFICATION }\end{array}$ & TOTAL OF CASES & CLL & $\mathrm{HL}$ & DLBCL, NOS & $B L$ & SMZL & ENMZL & B-LBL & AITL & FL & LPL \\
\hline Number (\%) & 66 & $23(34.8)$ & $17(25.8)$ & $14(21.2)$ & $5(7.6)$ & $2(3)$ & $1(1.5)$ & $1(1.5)$ & $1(1.5)$ & $1(1.5)$ & $1(1.5)$ \\
\hline Gender (\%) & $\begin{array}{l}M=44(66.7 \%) \\
F=22(33.3 \%)\end{array}$ & $\begin{array}{l}12(18.18) \\
11(16.6)\end{array}$ & $\begin{array}{l}13(19.7) \\
4(6)\end{array}$ & $\begin{array}{l}9(13.6) \\
5(7.5)\end{array}$ & $\begin{array}{l}4(6) \\
1(1.5)\end{array}$ & $\begin{array}{l}1(1.5) \\
1(1.5)\end{array}$ & $\begin{array}{l}1(1.5) \\
0\end{array}$ & $\begin{array}{l}1(1.5) \\
0\end{array}$ & $\begin{array}{l}1(1.5) \\
0\end{array}$ & $\begin{array}{l}1(1.5) \\
0\end{array}$ & $\begin{array}{l}1(1.5) \\
0\end{array}$ \\
\hline $\begin{array}{l}\text { M: } \mathbf{F} \\
(p=0.295)\end{array}$ & $2: 1$ & $1.1: 1$ & $3.3: 1$ & $1.8: 1$ & $4: 1$ & $1: 1$ & M & M & M & M & M \\
\hline $\begin{array}{l}\text { Age } \\
\text { Age range } \\
\text { Mean age }(p=0.574)\end{array}$ & $\begin{array}{l}2-85 \mathrm{yrs} \\
44.1 \mathrm{yrs}\end{array}$ & $\begin{array}{l}36-78 \mathrm{yrs} \\
55.7 \mathrm{yrs}\end{array}$ & $\begin{array}{l}4-64 \mathrm{yrs} \\
33.8 \mathrm{yrs}\end{array}$ & $\begin{array}{l}7-85 \mathrm{yrs} \\
46.1 \mathrm{yrs}\end{array}$ & $\begin{array}{l}7-65 \mathrm{yrs} \\
27.6 \mathrm{yrs}\end{array}$ & N.A. & N.A. & N.A. & N.A. & N.A. & N.A. \\
\hline Nodal (\%) & 55 (83.3\%) & $19(34.5)$ & $17(30.9)$ & $12(21.8)$ & $4(7.3)$ & 0 & 0 & $1(1.8)$ & $1(1.8)$ & $1(1.8)$ & 0 \\
\hline Extranodal (\%) & $11(16.7 \%)$ & $4(36.4)$ & 0 & $2(18.2)$ & $1(9.1)$ & $2(18.2)$ & $1(9.1)$ & 0 & 0 & 0 & $1(9.1)$ \\
\hline $\begin{array}{l}\text { EBV }(\%) \\
(p=0.023)\end{array}$ & $10(1.5 \%)$ & 0 & $6(60)$ & $1(10)$ & $3(30)$ & 0 & 0 & 0 & 0 & 0 & 0 \\
\hline
\end{tabular}

\section{Histology and immunohistochemistry (IHC)}

$4 \mu \mathrm{m}$ sections were cut and used for $H \& E$ staining and immunohistochemistry (IHC) from each block. All slides were reviewed by two expert hematopathologists (LL, $\mathrm{SL}$ ). Cases with insufficient or not optimal material were excluded from the study. The immunohistochemical analysis was performed with a panel of 25 antibodies commonly used in NHL and $\mathrm{HL}$ cases, using the Ventana staining system (Ventana, Tucson, AZ, USA).

\section{Detection of Epstein - Barr virus (EBV)}

According to the manufacturer's instruction, EBV was detected by in-situ-hybridization (ISH) using the INFORM EBER probe (Ventana Medical Systems, Inc., Tucson, AZ, USA). The slides were stained using an automated stainer (Benchmark Ultra, Ventana Medical Systems, Inc., Tucson, AZ, USA). The visualization was by ISH iView Blue Detection kit (Ventana Medical Systems, Inc., Tucson, AZ, USA) with alkaline phosphatase 5-bromo-4-chloro-3-indolyl phosphate/nitro blue tetrazolium (BCIP NBT/) substrate. Nuclear Fast red (Ventana Medical Systems, Inc., Tucson, AZ, USA) was used as a contrast. Appropriate positive and negative controls were set up parallel to the section analyzed.

\section{Results}

\section{Study cohort and clinical data}

A total of 152 cases were analyzed. From the study cohort's total number, 50 cases were excluded due to insufficient tissue materials or inadequate antigen reactivity. Of the remaining 102 samples, after using IHC, in only 66 cases, a lymphoma diagnosis was established. The remaining 36 cases were confirmed with the following diagnosis: 22 reactive lymphadenopathies, 2 Castleman disease (CD), 2 Rosai-Dorfman disease (RDD), and 10 cases as non-lymphoid malignancies. Among the 66 lymphoma cases, 44 (66.7\%) and 22 $(33.3 \%)$ were male and female, respectively, with a male to female ratio of 2:1 (Table 1). All the lymphoma subtypes showed a male predominance with higher ratios in HL (3.3:1) and BL (4:1). The lymphoma cases showed an age range between 2 and 85 years with a mean age of $44.4 \pm 20.1$ years that was not significantly different $(p=$ 0.295 ) among the two genders (male: 42.6 years; female: 48.1 years). As shown in Fig. 1, most lymphoid neoplasm (34.8\%) occurred within the age group of 41-60 years. The mean age of chronic lymphocytic leukemia (CLL) patients (55.7 years) was significantly different from the mean ages of patients with BL (27.6 years; $p=0.009)$ and HL (33.8 years; $p=0.001$ ) as opposed to the mean age of patients with DLBCL, NOS $(p=0.304)$.

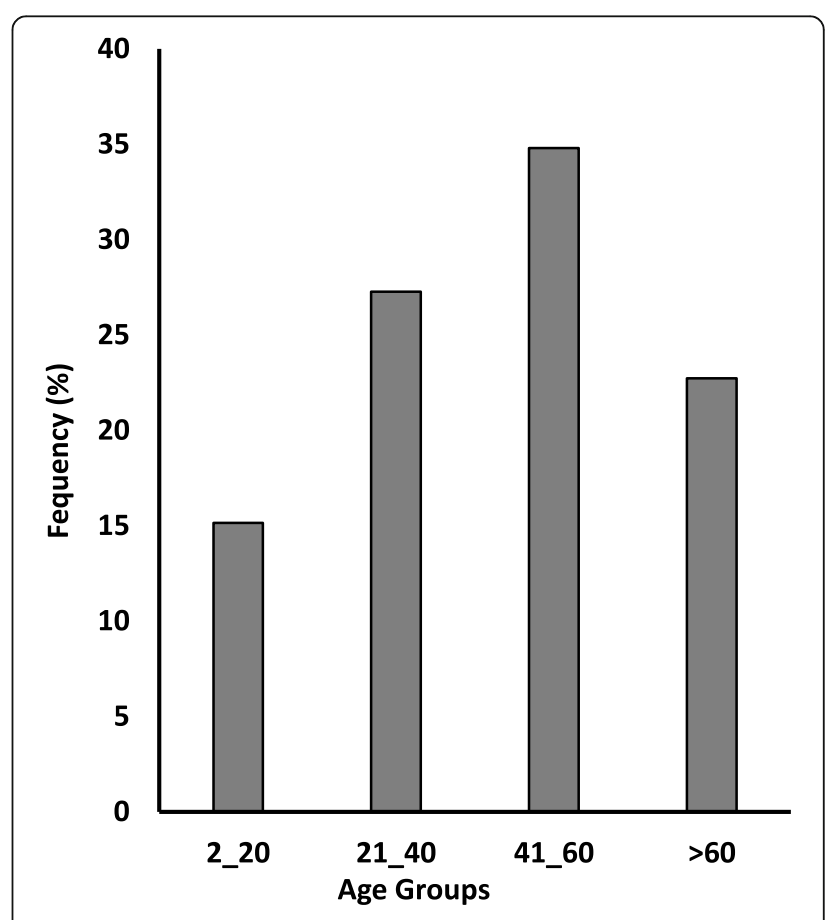

Fig. 1 Occurrence of lymphoid neoplasm and age distribution 
Also, in Table 1, nodal involvement (83.3\%) compared to extranodal sites (16.7\%) was more frequently observed in the different tumor types. Instead, the extranodal localizations according to the different lymphoid neoplasms were: 4 cases of CLL (omental mass, ovarian mass, breast, and colon), 2 for DLBCL, NOS (jaw and non-nodal tissue mass), 1 for BL (ovary), 2 for splenic marginal zone lymphoma (SMZL) (spleen), 1 for extranodal marginal zone lymphoma (ENMZL) (conjunctiva), and 1 for lymphoplasmacytic lymphoma (LPL) (scalp mass).

\section{Revised classification with immunohistochemistry of the 66 cases with lymphoma diagnosis}

The number of cases that were concordant and discordant from the previous diagnosis is shown in Table 2. The list of the antibody that was employed to reclassify are shown in Table 3. A total of 65 (98.5\%) cases originated by B lymphocytes while only one by $\mathrm{T}$ lymphocytes. The majority of the reclassified lymphomas were CLL $(n=23 ; 34.8 \%)$, and a greater proportion $(65.2 \%)$ of these cases came from the Hausa ethnic group (Table 4) involving mostly nodal sites (34.5\%). Only one case of the 23 CLL cases presented a concordant diagnosis while the other $22(95.6 \%)$ presented a discordant diagnosis (Supplementary Table 1). 17 cases of HL/HD (25.8\%) were identified with $5(29.4 \%)$ cases that presented a concordant diagnosis and the remaining 12 (70.6\%) cases of HL/HD were actually discordant from the original diagnosis (Supplementary Table 2). The highest incidence of HL/HD occurred within the age group of 21-40 years (Fig. 2), with a major frequency in the Yoruba ethnic group $(52.9 \%)$ as shown in

Table 2 Original diagnosis and revised diagnosis after expert revision and immunohistochemistry

\begin{tabular}{|c|c|c|c|c|c|c|c|c|c|c|c|}
\hline AL DIAGNO & & & & & & & & & & & \\
\hline $\begin{array}{l}\mathrm{BL} \\
n=2\end{array}$ & $\begin{array}{l}\text { CLL } \\
n=5\end{array}$ & $\begin{array}{l}\text { AITL } \\
n=2\end{array}$ & $\begin{array}{l}\text { DLBCL } \\
n=12\end{array}$ & $\begin{array}{l}\text { HL/HD } \\
n=6\end{array}$ & $\begin{array}{l}\text { PCM } \\
n=1\end{array}$ & $\begin{array}{l}\text { Reactive } \\
n=15\end{array}$ & $\begin{array}{l}\text { Carcinoma } \\
n=1\end{array}$ & $\begin{array}{l}\mathrm{FL} \\
n=1\end{array}$ & $\begin{array}{l}\text { NK lymphoma } \\
n=1\end{array}$ & $\begin{array}{l}\text { LPL } \\
n=1\end{array}$ & $\begin{array}{l}\text { MALT } \\
n=2\end{array}$ \\
\hline
\end{tabular}

\section{REVISED DIAGONSIS}

\begin{tabular}{|c|c|c|c|c|c|c|c|c|c|c|c|c|c|}
\hline $\begin{array}{l}\text { CLL } \\
n=23\end{array}$ & - & 1 & - & 4 & - & - & 1 & 1 & - & - & - & - & 16 \\
\hline $\begin{array}{l}\mathrm{HL} \\
n=17\end{array}$ & - & - & 1 & 1 & 5 & - & 2 & - & - & - & - & - & 8 \\
\hline $\begin{array}{l}\text { DLBCL } \\
n=14\end{array}$ & - & 1 & - & 4 & 1 & - & 1 & - & - & - & - & - & 7 \\
\hline $\begin{array}{l}\mathrm{BL} \\
n=5\end{array}$ & 2 & - & - & 1 & - & - & - & - & - & - & - & - & 2 \\
\hline $\begin{array}{l}\text { SMZL } \\
n=2\end{array}$ & - & 2 & - & - & - & - & - & - & - & - & - & - & - \\
\hline $\begin{array}{l}\text { ENMZL } \\
n=1\end{array}$ & - & - & - & - & - & - & - & - & - & 1 & - & - & - \\
\hline $\begin{array}{l}\text { B-LBL } \\
n=1\end{array}$ & - & - & - & - & - & - & 1 & - & - & - & - & - & - \\
\hline $\begin{array}{l}\text { AITL } \\
n=1\end{array}$ & - & - & - & 1 & - & - & - & - & - & - & - & - & - \\
\hline $\begin{array}{l}\mathrm{FL} \\
n=1\end{array}$ & - & - & - & - & - & - & - & - & - & - & - & - & 1 \\
\hline $\begin{array}{l}\mathrm{LPL} \\
n=1\end{array}$ & - & - & - & - & - & 1 & - & - & - & - & - & - & - \\
\hline $\begin{array}{l}\text { Sarcoma } \\
n=4\end{array}$ & - & - & - & - & - & - & - & - & - & - & - & - & 4 \\
\hline $\begin{array}{l}\text { Metastasis } \\
n=6\end{array}$ & - & - & 1 & 1 & - & - & - & - & - & - & - & 1 & 3 \\
\hline $\begin{array}{l}C D \\
n=2\end{array}$ & - & - & - & - & - & - & - & - & 1 & - & 1 & - & - \\
\hline $\begin{array}{l}\text { RDD } \\
n=2\end{array}$ & - & - & - & - & - & - & - & - & - & - & - & - & 2 \\
\hline $\begin{array}{l}\text { Reactive } \\
n=22\end{array}$ & - & 1 & - & - & - & - & 10 & - & - & - & - & 1 & 10 \\
\hline
\end{tabular}

AITL Angioimmunoblastic T-cell lymphoma, BL Burkitt lymphoma, B-LBL B-lymphoblastic leukaemia/lymphoma, CD Castleman disease, CLL chronic lymphocytic leukemia, $D L B C L$ diffuse large B-cell lymphomas, ENMZL extranodal marginal zone lymphoma, $F L$ follicular lymphoma, $H L$ Hodgkin lymphoma, $H D$ Hodgkin disease, LPL lymphoplasmacytic lymphoma, NHL non-Hodgkin lymphomas, PCM plasmacytoma, RDD Rosai-Dorfman disease, SMZL splenic marginal zone lymphoma 
Table 3 List of antibodies used

\begin{tabular}{llll}
\hline ANTIBODY & COMPANY & CLONE & DILUTION \\
\hline BCI-2 & Roche Ventana & SP66 & ready to use \\
BCI-6 & Cell Marque & Gl191E/A8 & $1: 50$ \\
CD 10 & Roche Ventana & SP67 & ready to use \\
CD 138 & Roche Ventana & B-A38 & ready to use \\
CD 15 & Roche Ventana & MMA & ready to use \\
CD 20 & Roche Ventana & L-26 & ready to use \\
CD 21 & Roche Ventana & 2G9 & ready to use \\
CD 23 & Roche Ventana & SP23 & ready to use \\
CD 3 & Roche Ventana & 2GV6 & ready to use \\
CICLINA D & Roche Ventana & SP4-R & ready to use \\
C-MYC & Roche Ventana & EP121 & ready to use \\
HHV8 & Roche Ventana & 13B10 & ready to use \\
KAPPA & Cell Marque & L1C1 & $1: 20$ \\
KI-67 & Roche Ventana & 309 & ready to use \\
LAMBDA & Cell Marque & LAMB14 & $1: 50$ \\
IGA & Cell Marque & 2652 & $1: 50$ \\
IGG & Cell Marque & 2653 & $1: 50$ \\
IGM & Cell Marque & 2654 & $1: 50$ \\
PAX5 & Roche Ventana & SP34 & ready to use \\
PD-1 & Cell Marque & NAT105 & $1: 20$ \\
S-100 & Roche Ventana & $4 C 4.9$ & ready to use \\
TDT & Cell Marque & TDT & $1: 100$ \\
\hline
\end{tabular}

Table 4. The distribution of the HL subtypes was: 4 (23.5\%) nodular lymphocyte-predominant Hodgkin lymphoma (NLPHL), 1 (5.9\%) lymphocyte rich classical Hodgkin lymphoma (LRCHL), 10 (58.8\%) of mixed cellularity classical Hodgkin lymphoma $(\mathrm{MCCH}$ L) and $2(11.8 \%)$ nodular sclerosis classical Hodgkin lymphoma (NSCHL). EBV infection was noticed in 6 cases of MCCHL. Following IHC and expert revision, 10 cases (71\%) out of 14 of the DLBCL group presented a discordant diagnosis (Supplementary Table 3). Instead, all the BL cases showed a concordant diagnosis in 2 cases (40\%) and the rest were discordant ( $n=3 ; 60 \%$ ), as shown in Supplementary Table 4. For the Igbo ethnic group, there was an identical distribution in the number of CLL (33.3\%), DLBCL, NOS (33.3\%), and HL/HD (33.3\%) as presented in Table 4.

The histologic diagnosis of the remaining 6 entities (Supplementary Table 5) were discordant with the final diagnosis according to the latest WHO classification: 2 SMZL (3\%), 1 ENMZL (1.5\%), 1 (1.5\%) follicular lymphoma (FL), 1 LPL (1.5\%), 1 (1.5\%) Blymphoblastic leukemia/lymphoma (B-LBL) and 1 (1.5\%) Angioimmunoblastic T-cell lymphoma (AITL). The representative slides of the H\&E and IHC are shown in Figs. 3, 4 and 5.

\section{Revised diagnosis of rare conditions and non-lymphoid neoplasm}

The non-lymphoid malignancies and other rare conditions that were more accurately diagnosed using IHC are shown in Supplementary Table 6. Apart from the identified rare conditions such as Castleman Disease ( $n=2 ; 14.3 \%)$, Rosai Dorfman Disease $(n=2 ; 14.3 \%)$, the rest of the cases were metastases of carcinomas $(n=6$; $43 \%)$ and sarcomas $(n=4 ; 28.6 \%)$.

\section{Cell of origin (COO)}

The COO determined by the Hans algorithm demonstrated that $10(71.4 \%)$ cases were of the Germinal Center type (GCB), 3 (21.4\%) were Non-Germinal Centre (non-GCB) type, and 1 (7.1\%) case could not be determined (Supplementary Table 3). Also, in both GCB and non-GCB subtypes, two of the DLBCL, NOS (14.3\%), presented co-expression of $\mathrm{c}-\mathrm{MYC}$ protein and BCL2 ("double expressors").

\section{Frequency of Epstein-Barr-virus in the lymphoma subtypes}

EBV was observed only in 10 cases (15.2\%): $6 \mathrm{HL}$ (60\%), $3 \mathrm{BL}(30 \%)$, and one case of DLBCL, EBV+. All the EBV positive cases of HL were MCCHL. The association between the presence of EBV and lymphoid neoplasm subtypes was statistically significant $(p=0.023)$.

\section{Discussion}

Detailed immunohistochemical characterization is needed to achieve a precise diagnosis to guarantee an

Table 4 Lymphoid neoplasm distribution in different population in Nigeria

\begin{tabular}{|c|c|c|c|c|c|c|c|c|c|c|c|}
\hline & $\begin{array}{l}\text { TOTAL } \\
(66)\end{array}$ & CLL (23) & $\begin{array}{l}\mathrm{HL} \\
(17)\end{array}$ & DLBCL, NOS (14) & $\begin{array}{l}\mathrm{BL} \\
(5)\end{array}$ & SMZL (2) & ENMZL (1) & B-LBL (1) & AITL (1) & $\begin{array}{l}\mathrm{FL} \\
(1)\end{array}$ & $\begin{array}{l}\text { LPL } \\
(1)\end{array}$ \\
\hline $\begin{array}{l}\text { Hausa/MHCL } \\
(n=59)\end{array}$ & $29(43.9 \%)$ & $15(65.2 \%)$ & $5(29.4 \%)$ & $7(50 \%)$ & $2(40 \%)$ & 0 & 0 & 0 & 0 & 0 & 0 \\
\hline $\begin{array}{l}\text { Igbo/ESUTH } \\
(n=46)\end{array}$ & $9(13.6 \%)$ & $3(13 \%)$ & $3(17.6 \%)$ & $3(21.4 \%)$ & 0 & 0 & 0 & 0 & 0 & 0 & 0 \\
\hline $\begin{array}{l}\text { Yoruba/UCH } \\
(n=47)\end{array}$ & $28(42.4 \%)$ & $5(21.7 \%)$ & $9(52.4 \%)$ & $4(28.6 \%)$ & $3(60 \%)$ & $2(100 \%)$ & $1(100 \%)$ & $1(100 \%)$ & $1(100 \%)$ & $1(100 \%)$ & $1(100 \%)$ \\
\hline
\end{tabular}




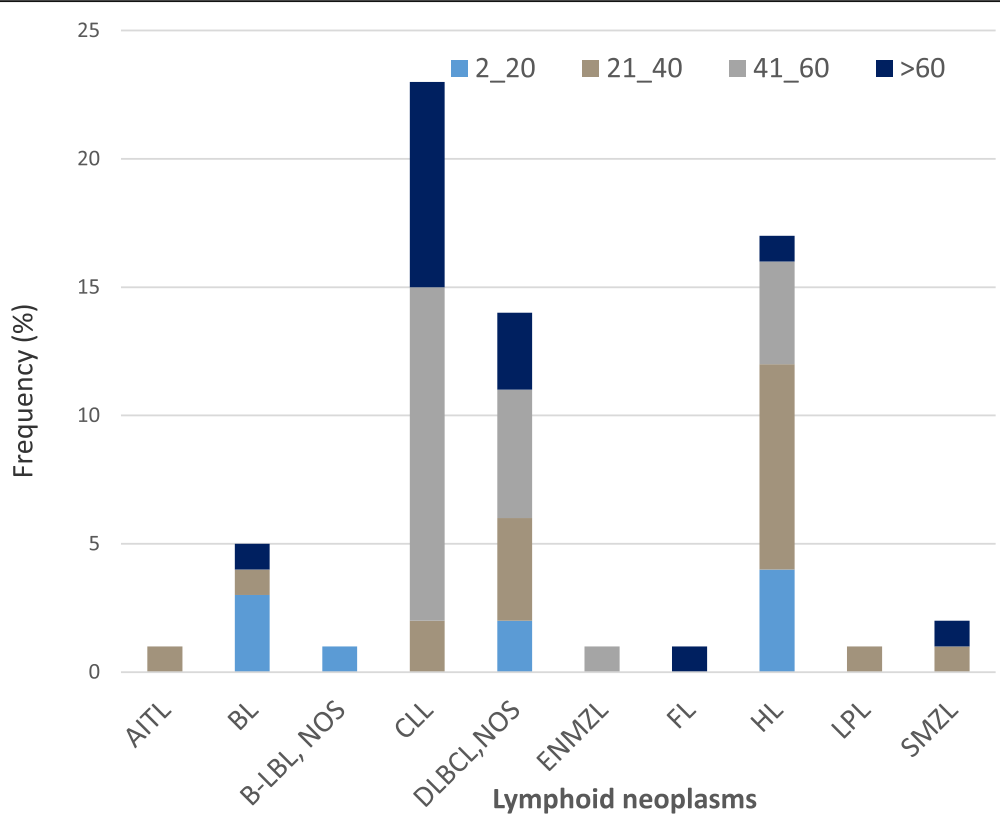

Fig. 2 Frequency of Lymphoid neoplasm subtypes within age groups. CLL/SLL-Chronic lymphocytic leukemia/small lymphocytic lymphoma, HLHodgkin lymphoma, DLBCL, NOS-Diffuse large B-cell lymphoma, not otherwise specified, BL- Burkitt lymphoma, SMZL-Splenic marginal zone Iymphoma, ENMZL- Extra nodal marginal zone lymphoma, FL-Follicular lymphoma, LPL- Lymphoplasmacytic lymphoma, AITL-Angioimmunoblastic T-cell lymphoma, B-LBL- B- lymphoblastic lymphoma

appropriate therapy for each lymphoid neoplasm, and this is often lacking in most tertiary hospitals in Nigeria [19]. This subject matter was an inspiration to re-assess all the lymphomas diagnoses that were made using only morphologic features with H\&E staining, which is mainly the only investigation available in many institutions in Nigeria.

In the present study, we aimed to reclassify the lymphoma cases adopting the latest WHO classification of lymphoid neoplasms, thus becoming the first study in Nigeria to provide updated data according to the WHO classification of lymphoid neoplasm. The majority of the classified lymphomas occurred within the age range of 41-60 years and were primarily from nodal sites, and these findings are similar to results from other populations [7]. The mean age of 44.4 years obtained in this article is comparable to other studies [21, 22]. A male predominance in the reclassified lymphoma cases and a lower prevalence of lymphoid neoplasms in females have been linked to the influence of estrogen on anti-tumor immune response [7, 23-25].

Interestingly, we observed a higher prevalence of CLL in our investigated population that differed from previous studies' results, where a higher incidence of DLBCL was reported $[21,26,27]$. The majority of the CLL cases were present in the Hausa group. HL was more frequently observed in the Yoruba group, while there was an identical distribution in the lymphoma subtypes identified in the
Igbo group. Evidence from previous studies of stereotyped $B$ cell receptors (BCR) in CLL suggests that common antigenic stimulation could be responsible for the pathogenesis of CLL [28]. It remains unknown whether this antigenic stimulation has ethnic diversity or genetic differences. Therefore, it may be interesting to investigate the frequency of possible common antigenic stimulation in CLL in this ethnic group compared to others.

After CLL, the second most frequent lymphoma was $\mathrm{HL}$, and MCCHL was the most recurrent subtype, that was also commonly associated with EBV infection. Although the HIV status of the studied population was not known, an earlier study had reported a low prevalence of HIV infection among adults in Nigeria [29]. Another study in the Northern part of Nigeria stated a $54.5 \%$ frequency of lymphomas correlated to EBV infection [26]. Moreover, the higher prevalence of the MCCHL subtype of HL compared to other HL subtypes was also similar to other populations $[27,30,31]$.

Instead, limited information is available on the frequency and distribution of DLBCL, NOS among Nigerian patients. In this study, we assessed the frequency of DLBCL, NOS and these were sub-classified based on the Hans algorithm. The proportion of the DLBCL, NOS GCB type was more recurrent than the non-GCB type. This data is somewhat different from several reports conducted on other sub-Saharan African, Asian, and Western cohorts, where a higher prevalence of the 

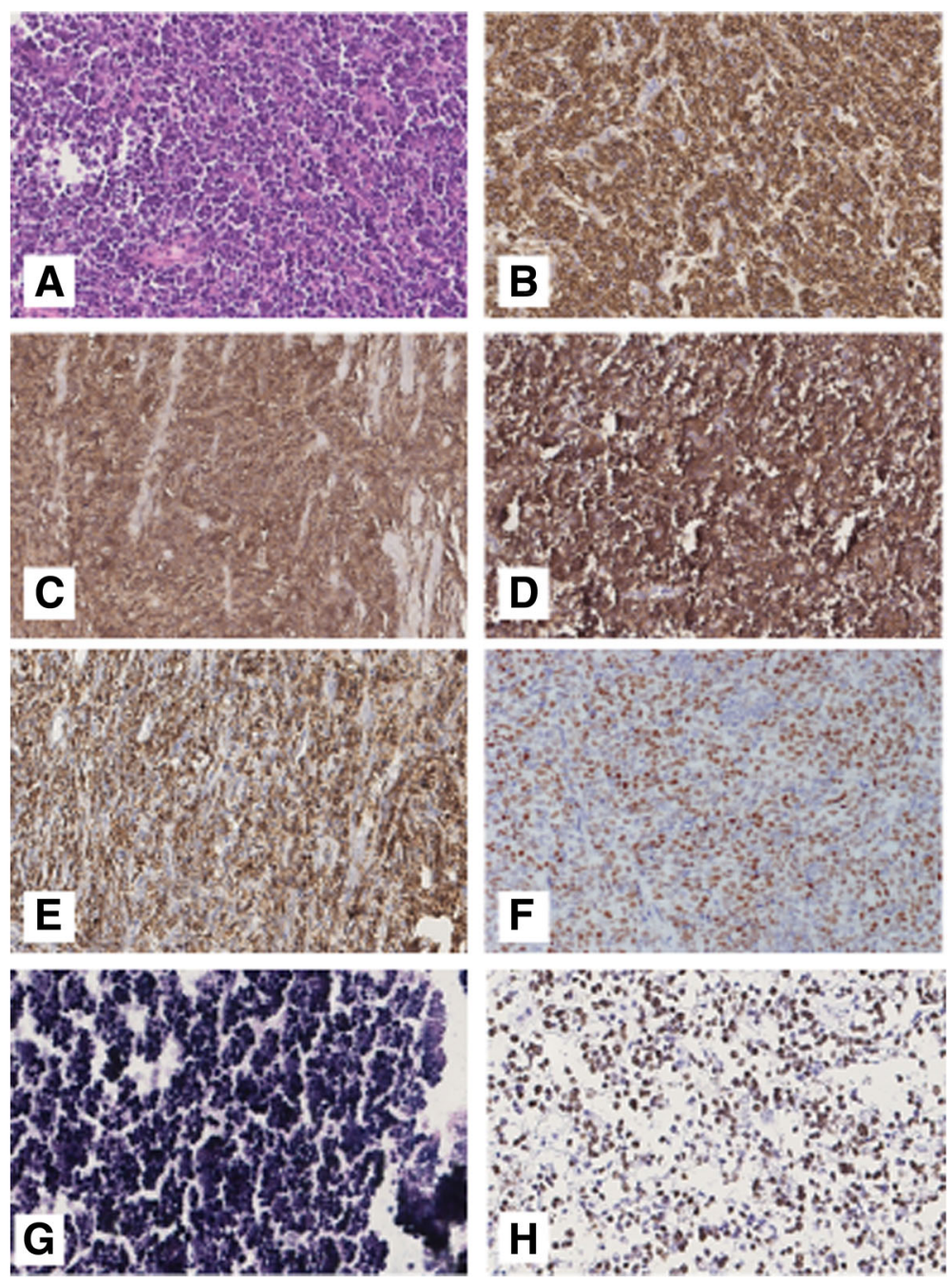

Fig. 3 Example of Diffuse Large B-cell Lymphoma. a. HE routine stain ( $\times 20)$. The neoplastic cell express CD20,CD10, BCL6, BCL2, MYC, EBER with high proliferation index evaluated with Ki67 (respectively in $\mathbf{b}, \mathbf{c}, \mathbf{d}, \mathbf{e}, \mathbf{f}, \mathbf{g}, \mathbf{h} \times 20$ )

DLBCL, NOS non-GCB type is observed [20, 32-35]. The co-expression of C-MYC and BCL2 proteins (double expressor) was seen in just two cases of the DLBCL, NOS. Even though double expressor DLBCL, NOS is commonly present in the non-GCB subtype, our result did not present any preference for a particular subset since the two double expressers were observed in both subgroups. DLBCL, NOS "double expressor" seems to correlate with a worst prognosis, but the double expression of these two proteins is not necessarily a surrogate indicator of double translocation of $c-M Y C$ and BCL2 genes ("double-hit lymphomas") $[36,37]$. Also, the 2 DLBCL "double expressor" cases were identified in nodal sites and this result is similar to earlier studies where a higher frequency of nodal involvement was appreciated [7, 38, 39].

The low frequency of AITL, FL, MZL, and B-LBL, NK-lymphomas in this study are consistent with similar distributions reported in prior African reports [40, 41]. Additionally, the low prevalence of EBV in lymphoma cases is also in line with earlier studies in Nigeria, where a decreased incidence of EBV-correlated lymphoid neoplasms was noticed [21, 26, 42]. Despite being classified as an endemic EBV area, the underlying causes for the EBV-associated lymphoma cases in Nigeria have not been highlighted yet. However, studies have shown that the former ideas of confining EBV infection to Africa and linking it to only BL were oversimplified [43].

The limit of the present study is the fact that the study cohort may not necessarily be representative of the true epidemiology of lymphoid neoplasms in Nigeria since we characterized only available cases rather than doing a prospective assessment. However, the study shows that classification of lymphomas based only on morphological features as it is commonly performed in developing countries, especially in Nigeria, reduces accurate 

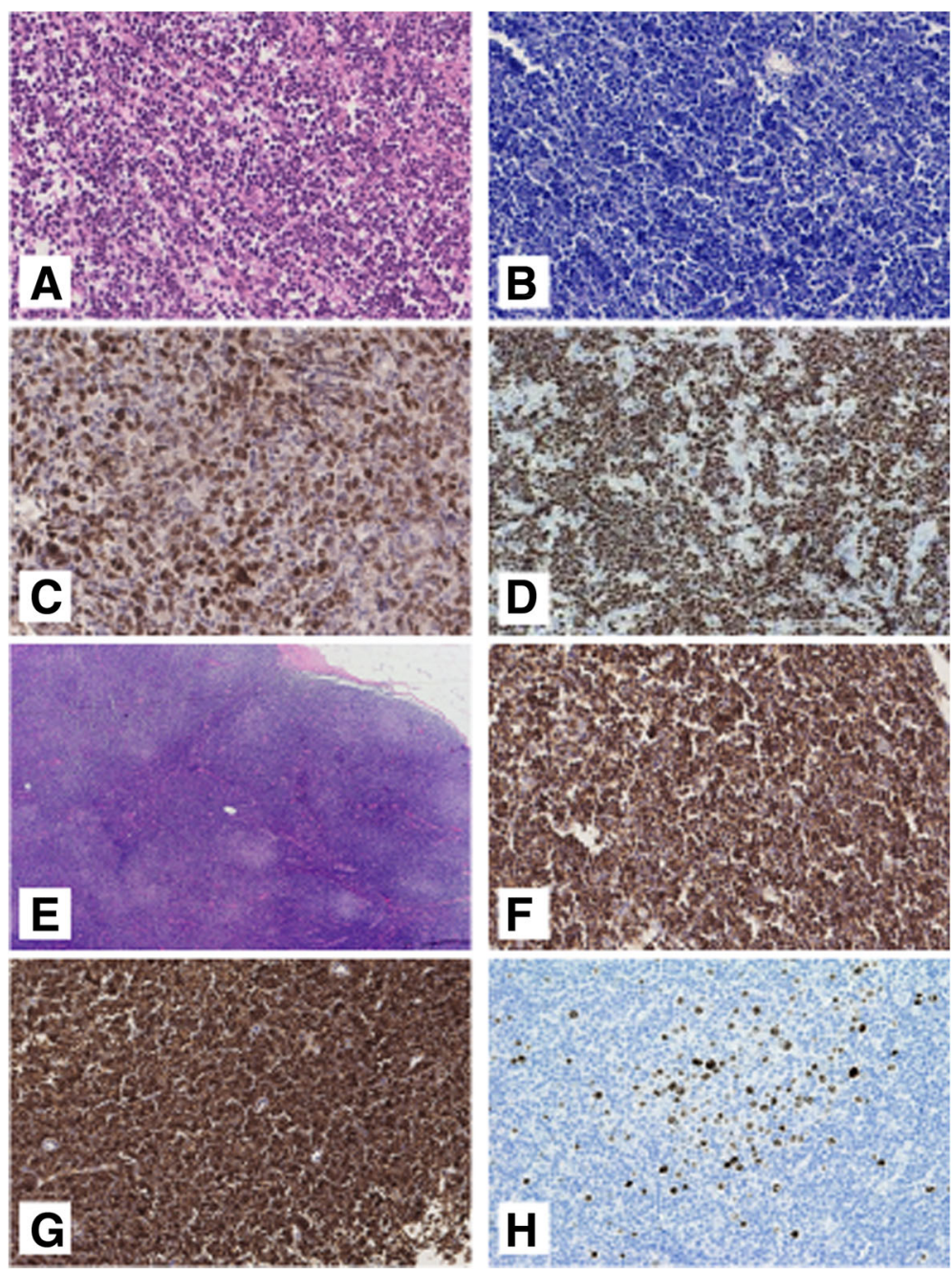

Fig. 4 a Burkitt lymphoma (HE routine stain $\times 20)$. b Giemsa stain $(\times 20)$. c C-MYC expression $(\times 40)$. d. Ki67 positivity $(\times 20)$. e Chronic lymphocytic leukemia (HE routine stain $\times 5$ ). $\mathbf{f}$ CD5 expression $(\times 20)$. $\mathbf{g}$ CD23 expression $(\times 20) . \mathbf{h}$ Cyclin D1 expression in the proliferation centre $(\times 20)$

diagnosis, thereby affecting patient management. The diagnostic approach has improved over the years, from the earliest attempt in 1942 by Gall and Mallory to the establishment in 1982 of the Working Formulation (WF) classification system, which in 1994 was later replaced by the Revised European-American (REAL) classification of lymphoid neoplasms [44-46]. The harmonization and the update of the REAL classification by the WHO have provided a more uniform classification for lymphoid neoplasms $[6,11,47]$. The importance of immunohistochemistry in diagnosing lymphoma in Nigeria has been emphasized in several studies carried out in different centers $[19,21,48,49]$.

Furthermore, prior studies have proposed diagnostic algorithms to support minimal immunohistochemical panels to achieve a B-cell lymphoma diagnosis, mainly in institutions with limited resources, before considering consultation in specialized centers [50]. The present study demonstrates how a more collaborative effort is necessary to incorporate routine immunohistochemical analysis to achieve accurate lymphoma diagnosis in Nigeria. Specific diagnosis could be achieved in specialized regional centers of excellence, where advanced tests can be performed, and in this manner, sparse and expensive resources like antibodies can be pulled together to serve a broader population.

\section{Conclusion}

The present study describes morphology-based diagnosis in resource-constrained hospitals in Nigeria that were reclassified according to the WHO after immunohistochemical assessment and also showing different distribution of lymphoid neoplasm in Nigeria. Furthermore, we found interesting distributions and variability of some 

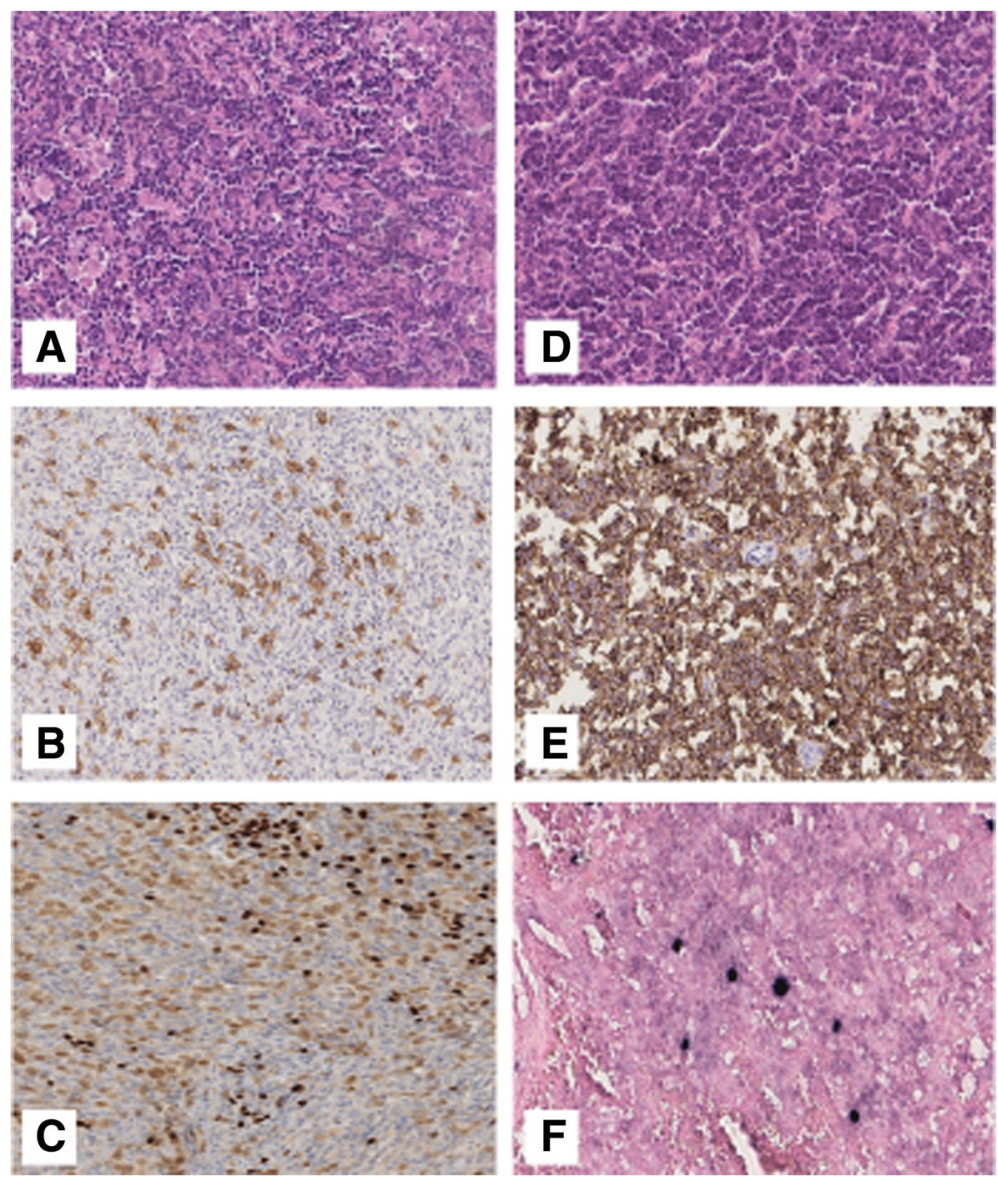

Fig. 5 a Classical Hodgkin Lymphoma (HE routine stain $\times 20)$. b The neoplastic cells are positive for CD30 $(\times 20)$, c Weak positivity for PAX5. d Angioimmunoblastic T-cell lymphoma (HE routine stain $\times 20$ ), e CD10 expression $(\times 20)$, f Scattered large cells positive for EBER $(\times 40)$

lymphoid tumors from the previously available literature. In our study cohort, CLL is the most frequent lymphoma, and this data underscores the prevalence of indolent lymphomas rather than aggressive lymphoproliferative neoplasms. Moreover DLBCL, NOS GCB type was the most common, although to evaluate the reliability of this information more investigations with larger cohorts are required. Also, we have documented that the association of EBV with lymphomas in this region is surprisingly low. Implementing the updated WHO classification in developing countries, especially Nigeria, will refine the diagnostic process and improve patient management in lymphoid neoplasms.

\section{Supplementary Information}

The online version contains supplementary material available at https://doi. org/10.1186/s13027-021-00378-z.

\section{Additional file 1. \\ Additional file 2. \\ Additional file 3. \\ Additional file 4.}

\section{Additional file 5.}

Additional file 6 .

\section{Acknowledgements}

We wish to thank members of staff and management of the Pathology Departments of ESUTH, UCH and MEENA Histopathology Laboratory. We also thank all the staff and management of Anatomical Pathology Department of the University of Siena, Italy.

\section{Authors' contributions}

OA \& IAT designed the study; LL \& ICU contributed to the design of the study. MAD, OA, and ICU were involved in the selection of cases and acquisition of clinical data; LL, SL, MG, ICU and GDS participated in the staining and scoring of the immunohistochemistry slides, and insituhybridisation methods for detection of Epstein-Barr virus; SM \& ES performed other special staining and evaluated the antibodies; ICU and IAT wrote the draft and OA provided critical revision of the manuscript. All authors read and approved the final manuscript.

\section{Funding}

This work was supported by the Union for International Cancer Control (UICC) Technical Fellowships grant, 2019.

Availability of data and materials This is not applicable to this study. 


\section{Declarations}

\section{Ethics approval and consent to participate}

The study protocol complied with ethical standards and was approved by the Ethical Board of each study jurisdictions; University of Nigeria Teaching Hospital, Enugu (UNTH-NHREC/05/01/2008B), Ministry of Health, Ibadan, Oyo State (AD13/479/1138), and Meena Histopathology and Cytology Laboratory, Jos, Plateau State (MEENALAB/AEC/177).

\section{Consent for publication}

The author(s) read and approved the final manuscript.

\section{Competing interests}

The authors declare no competing interest.

\begin{abstract}
Author details
${ }^{1}$ Molecular-Haematology Laboratory, Department of Medical Laboratory Science, College of Medicine, College of Medicine, University of Nigeria Nsukka, Enugu Campus, Enugu, Nigeria. ${ }^{2}$ Genetics Laboratory, Department of Cell Biology and Genetics, Faculty of Science, University of Lagos, Lagos, Nigeria. ${ }^{3}$ Centre for Genomics of Non-communicable Diseases and Personalized Healthcare (CGNPH), University of Lagos, Lagos, Nigeria. ${ }^{4}$ Institute of Pathology, University Hospital of Tübingen, Tübingen, Germany. ${ }^{5}$ Section of Pathology, Department of Medical Biotechnology, University of Siena, Siena, Italy. ${ }^{6}$ Department of Haematology, Obafemi Awolowo University Teaching Hospital Complex, Ile-lfe, Nigeria. ${ }^{7}$ Clinical Chemistry and Molecular Diagnostics Laboratory, Department of Medical Laboratory Sciences, Faculty of Basic Medical Centre, College of Medicine, University of Lagos, Lagos, Nigeria.
\end{abstract}

\section{Received: 21 January 2021 Accepted: 12 May 2021}

\section{Published online: 24 May 2021}

\section{References}

1. Cerhan JR, Slager SL. Familial predisposition and genetic risk factors for lymphoma. Blood. 2015;126(20):2265-73. https://doi.org/10.1182/blood-201 5-04-537498.

2. Busolo DS, Woodgate RL. Cancer prevention in Africa: a review of the literature. Glob Health Promot. 2015;22(2):31-9. https://doi.org/10.1177/1 757975914537094

3. Miranda-Filho A, Pineros M, Znaor A, Marcos-Gragera R, Steliarova-Foucher E, Bray F. Global patterns and trends in the incidence of non-Hodgkin lymphoma. Cancer Causes Control. 2019;30(5):489-99. https://doi.org/10.1 007/s10552-019-01155-5.

4. Oluwasola AO, Olaniyi JA, Otegbayo JA, Ogun GO, Akingbola TS, Ukah CO, et al. A fifteen-year review of lymphomas in a Nigerian tertiary healthcare Centre. J Health Popul Nutr. 2011;29(4):310-6.

5. Omoti CE, Halim NK. Adult malignant lymphomas in University of Benin Teaching Hospital, Benin City, Nigeria--incidence and survival. Niger J Clin Pract. 2007:10(1):10-4.

6. Swerdlow SH, Campo E, Pileri SA, Harris NL, Stein H, Siebert R, et al. The 2016 revision of the World Health Organization classification of lymphoid neoplasms. Blood. 2016;127(20):2375-90. https://doi.org/10.1182/blood-201 6-01-643569.

7. Yoon SO, Suh C, Lee DH, Chi HS, Park CJ, Jang SS, et al. Distribution of lymphoid neoplasms in the Republic of Korea: analysis of 5318 cases according to the World Health Organization classification. Am J Hematol. 2010;85(10):760-4. https://doi.org/10.1002/ajh.21824.

8. Jaffe ES. Diagnosis and classification of lymphoma: impact of technical advances. Semin Hematol. 2019;56(1):30-6. https://doi.org/10.1053/j. seminhematol.2018.05.007.

9. Tomoka T, Montgomery ND, Powers E, Dhungel BM, Morgan EA, Mulenga $M$, et al. Lymphoma and pathology in sub-Saharan Africa: current approaches and future directions. Clin Lab Med. 2018;38(1):91-100. https:// doi.org/10.1016/j.cll.2017.10.007

10. King BE, Chen C, Locker J, Kant J, Okuyama K, Falini B, et al. Immunophenotypic and genotypic markers of follicular center cell neoplasia in diffuse large B-cell lymphomas. Mod Pathol. 2000;13(11):1219-31. https:// doi.org/10.1038/modpathol.3880226.

11. Campo E, Swerdlow SH, Harris NL, Pileri S, Stein H, Jaffe ES. The 2008 WHO classification of lymphoid neoplasms and beyond: evolving concepts and practical applications. Blood. 2011;117(19):5019-32. https://doi.org/10.1182/ blood-2011-01-293050

12. Swerdlow SH. Lymphoma classification and the tools of our trade: an introduction to the 2012 USCAP long course. Mod Pathol. 2013;26(Suppl 1): S1-S14. https://doi.org/10.1038/modpathol.2012.177.

13. Kadry DY, Khorshed AM, Rashed RA, Mokhtar NM. Association of Viral Infections with risk of human lymphomas, Egypt. Asian Pac J Cancer Prev. 2016;17(4):1705-12. https://doi.org/10.7314/apjcp.2016.17.4.1705.

14. Odutola M, Jedy-Agba EE, Dareng EO, Oga EA, Igbinoba F, Otu T, et al. Burden of cancers attributable to infectious agents in Nigeria: 2012-2014. Front Oncol. 2016;6:216. https://doi.org/10.3389/fonc.2016.00216.

15. Shannon-Lowe C, Rickinson AB, Bell Al. Epstein-Barr virus-associated lymphomas. Philos Trans R Soc Lond Ser B Biol Sci. 2017;372(1732): 20160271. https://doi.org/10.1098/rstb.2016.0271.

16. Greifenegger $N$, Jäger $M$, Kunz-Schughart LA, Wolf H, Schwarzmann F. Epstein-Barr virus small RNA (EBER) genes: differential regulation during lytic viral replication. J Virol. 1998;72(11):9323-8. https://doi.org/10.1128/JVI.72.11. 9323-9328.1998

17. Brown BJ, Bamgboye EA, Sodeinde O. Early deaths and other challenges to childhood cancer survival in Ibadan, Nigeria. Cent Afr J Med. 2008;54(5-8): $32-9$

18. Chukwu BF, Ezenwosu OU, Ikefuna AN, Emodi IJ. Diagnostic delay in pediatric cancer in Enugu, Nigeria: a prospective study. Pediatr Hematol Oncol. 2015;32(2):164-71. https://doi.org/10.3109/08880018.2014.957368.

19. Akinde O, Anunobi C, Osunkalu O, Phillips A, Afolayan O. The challenges of lymphoma diagnosis in a tertiary Hospital in Lagos, Nigeria. J Clin Sci. 2016; 13(2):58-71. https://doi.org/10.4103/2408-7408.179679.

20. Hans CP, Weisenburger DD, Greiner TC, Gascoyne RD, Delabie J, Ott G, et al. Confirmation of the molecular classification of diffuse large B-cell lymphoma by immunohistochemistry using a tissue microarray. Blood. 2004; 103(1):275-82. https://doi.org/10.1182/blood-2003-05-1545.

21. Onwubuya IM, Adelusola KA, Durosinmi MA, Sabageh D, Ezike KN. Lymphomas in Ile-Ife, Nigeria: Immunohistochemical characterization and detection of Epstein-Barr virus encoded RNA. J Clin Diagn Res. 2015;9(6): EC14-9. https://doi.org/10.7860/JCDR/2015/12085.6127.

22. Sultan S, Irfan SM, Rashid A, Parveen S, Nawaz N. Clinico-hematological profile of 184 patients with non-Hodgkin's lymphoma: an experience from southern Pakistan. Gulf J Oncolog. 2017:1(25):11-4.

23. Smith A, Crouch S, Lax S, Li J, Painter D, Howell D, et al. Lymphoma incidence, survival and prevalence 2004-2014: sub-type analyses from the UK's Haematological malignancy research network. Br J Cancer. 2015;112(9): 1575-84. https://doi.org/10.1038/bjc.2015.94

24. Diumenjo MC, Abriata G, Forman D, Sierra MS. The burden of non-Hodgkin lymphoma in central and South America. Cancer Epidemiol. 2016;44:S16877. https://doi.org/10.1016/j.canep.2016.05.008.

25. Horesh N, Horowitz NA. Does gender matter in non-Hodgkin lymphoma? Differences in epidemiology, clinical behavior, and therapy. Rambam Maimonides Med J. 2014;5(4):e0038. https://doi.org/10.5041/RMMJ.10172.

26. Iliyasu Y, Ayers LW, Liman AA, Waziri GD, Shehu SM. Epstein -Barr virus association with malignant lymphoma subgroups in Zaria, Nigeria. Niger J Surg Sci. 2014;23(1):6-8. https://doi.org/10.4103/1116-5898.127096.

27. Shahid R, Gulzar R, Avesi L, Hassan S, Danish F, Mirza T. Immunohistochemical profile of Hodgkin and non-Hodgkin lymphoma. J Coll Physicians Surg Pak. 2016;26(2):103-7 doi:02.2016/JCPSP.103107.

28. Rossi D, Gaidano G. Biological and clinical significance of stereotyped B-cell receptors in chronic lymphocytic leukemia. Haematologica. 2010;95(12): 1992-5. https://doi.org/10.3324/haematol.2010.033241.

29. Awofala AA, Ogundele OE. HIV epidemiology in Nigeria. Saudi J Biol Sci. 2018;25(4):697-703. https://doi.org/10.1016/j.sjbs.2016.03.006.

30. Hashemi-Bahremani M, Parwaresch MR, Tabrizchi H, Gupta RK, Raffii MR (2007) Lymphomas in Iran. Arch Iran med 10 (3):343-348. Doi:07103/AIM.0012.

31. Mushtaq S, Akhtar N, Jamal S, Mamoon N, Khadim T, Sarfaraz T, et al. Malignant lymphomas in Pakistan according to the WHO classification of lymphoid neoplasms. Asian Pac J Cancer Prev. 2008;9(2):229-32.

32. Chen Y, Xiao L, Zhu X, Lu C, Yu B, Fan D, et al. Immunohistochemical classification and prognosis of diffuse large B-cell lymphoma in China. Zhonghua Bing Li Xue Za Zhi. 2014;43(6):383-8.

33. Morgan EA, Sweeney MP, Tomoka T, Kopp N, Gusenleitner D, Redd RA, et al. Targetable subsets of non-Hodgkin lymphoma in Malawi define therapeutic opportunities. Blood advances. 2016:1(1):84-92. https://doi.org/10.1182/ bloodadvances. 2016000026 . 
34. Ichiki A, Carreras J, Miyaoka M, Kikuti YY, Jibiki T, Tazume K, et al. Clinicopathological analysis of 320 cases of diffuse large B-cell lymphoma using the Hans classifier. J Clin Exp Hematop. 2017;57(2):54-63. https://doi. org/10.3960/jslrt.17029.

35. Hwang HS, Yoon DH, Hong JY, Park CS, Lee YS, Ko YH, et al. The cell-oforigin classification of diffuse large B cell lymphoma in a Korean population by the Lymph2Cx assay and its correlation with immunohistochemical algorithms. Ann Hematol. 2018;97(12):2363-72. https://doi.org/10.1007/s002 77-018-3442-2

36. Johnson NA, Slack GW, Savage KJ, Connors JM, Ben-Neriah S, Rogic S, et al. Concurrent expression of MYC and BCL2 in diffuse large B-cell lymphoma treated with rituximab plus cyclophosphamide, doxorubicin, vincristine, and prednisone. J Clin Oncol. 2012;30(28):3452-9. https://doi.org/10.1200/jco.2 011.41.0985.

37. Scott DW, Mottok A, Ennishi D, Wright GW, Farinha P, Ben-Neriah S, et al. Prognostic significance of diffuse large B-cell lymphoma cell of origin determined by digital gene expression in formalin-fixed paraffin-embedded tissue biopsies. J Clin Oncol. 2015;33(26):2848-56. https://doi.org/10.1200/ jco.2014.60.2383.

38. Beham-Schmid C. Aggressive lymphoma 2016: revision of the WHO classification. Memo. 2017;10(4):248-54. https://doi.org/10.1007/s12254-0170367-8.

39. Aggarwal D, Gupta R, Singh S, Kudesia M. Comparison of working formulation and REAL classification of non-Hodgkin's lymphoma: an analysis of 52 cases. Hematology. 2011;16(4):195-9. https://doi.org/10.1179/1024 $53311 \times 13025568941718$

40. Tomoka T, Powers E, van der Gronde T, Amuquandoh A, Dhungel BM, Kampani C, et al. Extranodal natural killer/T-cell lymphoma in Malawi: a report of three cases. BMC Cancer. 2017;17(1):633. https://doi.org/10.1186/ s12885-017-3612-y.

41. Naresh KN, Raphael M, Ayers L, Hurwitz N, Calbi V, Rogena E, et al. Lymphomas in sub-Saharan Africa--what can we learn and how can we help in improving diagnosis, managing patients and fostering translational research? Br J Haematol. 2011;154(6):696-703. https://doi.org/10.1111/j.13 65-2141.2011.08772.x.

42. Adelusola KA, Titiloye NA, Rotimi O, Durosinmi M. Epstein Barr virus latent membrane protein-1 in Hodgkin's lymphoma in Nigerians. Afr Health Sci. 2009;9(3):174-8

43. Gandhi MK. Epstein-Barr virus-associated lymphomas. Expert Rev Anti-Infect Ther. 2006;4(1):77-89. https://doi.org/10.1586/14787210.4.1.77.

44. Gall EA, Mallory TB. Malignant lymphoma: a Clinico-pathologic survey of 618 cases. Am J Pathol. 1942;18(3):381-429.

45. Rosenberg SABC, Brown BW, Dorfmann RF, Glastein E, Hoppe RT, Richard S, et al. National Cancer Institute sponsored study of classifications of nonHodgkin's lymphomas: summary and description of a working formulation for clinical usage. The non-Hodgkin's lymphoma pathologic classification project. Cancer. 1982;49(10):2112-35. https://doi.org/10.1002/1097-0142 (19820515)49:10<2112::aid-cncr2820491024>3.0.co;2-2.

46. Harris NL, Jaffe ES, Stein H, Banks PM, Chan JK, Cleary ML, et al. A revised European-American classification of lymphoid neoplasms: a proposal from the international lymphoma study group. Blood. 1994;84(5):1361-92. https:// doi.org/10.1182/blood.V84.5.1361.1361.

47. Chan JK. The new World Health Organization classification of lymphomas: the past, the present and the future. Hematol Oncol. 2001;19(4):129-50. https://doi.org/10.1002/hon.660.

48. Obumneme ON, Uche I, Adekunbiola B, Ralph A, Nicholas I. Follicular lymphoma in situ presenting as dermatopathic lymphadenopathy. Case Rep Pathol. 2013;2013:481937-4. https://doi.org/10.1155/2013/481937.

49. Adelusola KA, Adeniji KA, Somotun GO. Lymphoma in adult Nigerians. West Afr J Med. 2001;20(2):123-6.

50. Disanto MG, Ambrosio MR, Rocca BJ, Ibrahim HAH, Leoncini L, Naresh KN. Optimal minimal panels of immunohistochemistry for diagnosis of B-cell lymphoma for application in countries with limited resources and for triaging cases before referral to specialist centers. Am J Clin Pathol. 2016; 145(5):687-95. https://doi.org/10.1093/ajcp/aqw060.

\section{Publisher's Note}

Springer Nature remains neutral with regard to jurisdictional claims in published maps and institutional affiliations.

\section{Ready to submit your research? Choose BMC and benefit from}

- fast, convenient online submission

- thorough peer review by experienced researchers in your field

- rapid publication on acceptance

- support for research data, including large and complex data types

- gold Open Access which fosters wider collaboration and increased citations

- maximum visibility for your research: over $100 \mathrm{M}$ website views per year

At BMC, research is always in progress.

Learn more biomedcentral.com/submissions 